\title{
Psikologi Amanah: Konsep, Pengukuran, dan Tantangan
}

\section{Psychology of Amanah: Concepts, Measurement, and Challenges}

\author{
Ivan Muhammad Agung* \\ *Universitas Islam Negeri Sultan Syarif Kasim Riau
}

\begin{abstract}
Abstrak. Amanah merupakan salah satu konsep penting dalam kepribadian Islam. Konsep amanah telah banyak diskusikan dalam perspektif Islam, Namun belum banyak penelitian amanah dalam perspektif psikologi. Artikel ini mencoba mereview dan mendiskusikan konsep amanah dalam perspektif psikologi, yang terdiri dari bagian, Pertama, apa itu amanah? Kedua, hubungan amanah, psikologi dan Islam. Ketiga pengukuran amanah. Keempat, pentingnya amanah bagi individu, masyarakat, dan organisasi. Terakhir, peluang dan tantangan penelitian amanah. Hasilnya menunjukkan bahwa konstruk amanah bersifat kompleks dan multidimensi, karena melibatkan hubungan interpersonal (horizontal), dan hubungan dengan Allah (vertikal). Oleh karena itu, perlu dieksplorasi dari perspektif psikologi melalui penelitian-penelitian empiris. Beberapa studi menunjukkan bahwa penelitian amanah memiliki beragam teori, sehingga berimplikasi pada perbedaan pengukuran amanah. Sementara itu, peluang dan tantangan dalam penelitian amanah akan diskusikan dalam artikel ini dalam konteks teoritis, metodologis, dan praktis.
\end{abstract}

Kata kunci: amanah; kebajikan; kepribadian; pengukuran; psikologi Islam

Abstract. Amanah is one of the important concepts in Islamic personality. The concept of amanah has been widely discussed in the Islamic perspective, but there has been little research on amanah in the psychological perspective. This article tried to review and discuss the concept of amanah from a psychological perspective, which comprises parts, first, what is amanah? Second, the relationship of amanah, psychology, and Islam. Third, amanah measurement. Fourth, the importance of amanah for individuals, society, and organizations. Finally, the opportunities and challenges of amanah research. The results show that the amanah is a complex and multidimensional construct because it involves interpersonal relationships (horizontal), and relationships with God (vertical). Therefore, it needs to be explored from a psychological perspective through empirical studies. Several studies have shown that amanah research has a variety of theories, so it has implications for the difference in amanah measurement. Meanwhile, opportunities and challenges in amanah research will be discussed in this article in theoretical, methodological, and practice contexts.

Keywords: amanah; islamic psychology; measurement; personality; virtue 


\section{Pengantar}

Amanah sebagai suatu nilai kebajikan (virtue) yang dianut dan dijadikan pedoman dalam individu berperilaku amanah merupakan salah satu konsep penting dalam Islam. Amanah merupakan salah satu sifat dan karakter para nabi, yang diartikan sebagai orang yang memiliki sifat dapat dipercaya, jujur, dan bertanggung jawab (Abidin, 2017; Shuhari et al., 2019; Tekke et al., 2018). Orang yang amanah adalah orang yang mampu menjalankan segala peran dan tugas yang diberikan kepadanya (Agung \& Husni, 2016; Othman, 2011; Sari \& Sofia, 2018). Peran amanah sangat besar dalam kehidupan manusia. Amanah merupakan daya tarik (pengikat) dalam hubungan interpersonal manusia, tanpa amanah kehidupan manusia akan hancur, tidak ada rasa percaya, khianat dan rasa permusuhan (Hamka, 1990). Selain itu, aplikasi konsep amanah tidak hanya dalam tataran individu, tetapi juga pada level pendidikan, organisasi, bisnis, dan ekonomi (Kalbarini \& Suprayogi, 2015; Suprihatiningrum \& Premono, 2012) Konsep amanah telah menjadi daya tarik bagi para ahli dari berbagai disiplin ilmu, namun secara konsep operasional dan empiris masih belum banyak dikaji secara empiris khususnya dalam tataran ilmu psikologi. Kajian empiris tentang konsep amanah dapat memperjelas kedudukan konsep amanah, sehingga berimplikasi pada pengukuran konsep amanah yang lebih akurat dan tepat. Lebih lanjut, penelitian tentang amanah dapat jadikan referensi keilmuan khususnya dalam psikologi Islam dan pengembangan nilai bagi individu dan organisasi. Sampai saat ini penelitian amanah banyak dilakukan pada negara mayoritas Islam, seperti Malaysia. Sementara di Indonesia, konsep amanah telah mulai diteliti secara empiris. Secara konsep, amanah sangat dekat dengan konsep psikologi seperti kepercayaan (trust), terpercaya (Trustworthiness), tanggung jawab, dan jujur. Namun terdapat beberapa hal yang membedakan antara amanah dengan konsep psikologi tersebut. Tulisan ini mengeksplorasi konsep dan definisi amanah dalam pendekatan penelitian pustaka dan lapangan. Selanjutnya, tulisan ini mendiskusikan peran dan pengukuran amanah, serta mencoba menjelaskan tantangan dan peluang penelitian amanah.

\section{Pembahasan}

\section{Peran dan Kontribusi Amanah}

Apa pentingnya amanah? Sejauh mana peran amanah dalam kehidupan manusia? Apa kontribusi penelitian amanah dalam pembentukan karakter positif manusia? Banyak pertanyaan-pertanyaan muncul ketika kita membahas tentang amanah. Amanah merupakan suatu konsep yang sering didengar, tapi jarang dilakukan eksplorasi ilmiah dalam perspektif ilmu psikologi. Sebagai suatu nilai-yang menjadikan rujukan dalam berperilaku, amanah menjadi penting diaplikasikan dalam kehidupan sehari-hari. Amanah memiliki peran penting pada kondisi psikologis dan perilaku individu (Samsudin \& Islam, 2015). Tidak hanya itu, amanah menjadi fondasi kuat dalam relasi antar individu, organisasi, dan negara. Tanpa perilaku amanah, tidak ada kepercayaan dalam relasi interpersonal maupun organisasi. Akibatnya muncul perilaku khianat, korupsi, kriminal, dan tidak bertanggung jawab (Kholmi, 2012). Jadi, amanah memungkinkan manusia untuk menghilangkan 
kebodohan, ketidakadilan, pengkhianatan, dan sebagainya dari masyarakat, sehingga menciptakan lingkungan yang lebih damai (Hamka, 1990; Samsudin \& Islam, 2015).

Kepribadian amanah memiliki peran dan kontribusi nyata dalam kehidupan manusia. Ada dua hal yang dapat dieksplorasi manfaat dari konsep amanah, yaitu pengembangan teoritis dan keilmuan, dan implikasi praktis. Pertama, pengembangan konsep amanah dapat melalui kajian dan penelitian tentang amanah sehingga dapat memberikan wawasan keilmuan dalam bidang psikologi khususnya psikologi Islam. Beberapa penelitian menunjukkan bahwa perilaku amanah bermanfaat pada individu dan organisasi, misalkan, kepribadian amanah membantu dalam meningkatkan kualitas psikologis individu. Hasil penelitian (Tranajaya, 2011) bahwa perilaku amanah dapat meningkatkan etos kerja individu. Orang yang amanah berusaha melaksanakan tugas dan tanggung jawabnya. Pribadi yang amanah akan selalu berprinsip bahwa pekerjaan harus diselesaikan dengan sebaik-baiknya. Selain itu, amanah juga dapat meningkatkan kesejahteraan psikologis individu (Hasibuan et al., 2018). Hasil penelitian Tekke et al. (2018) menunjukkan bahwa amanah berhubungan dengan peningkatan self esteem, pengetahuan diri, empati, dan tanggung jawab sosial. Individu yang memiliki sifat dan perilaku amanah cenderung memiliki perilaku tanggung jawab, percaya diri, berpikir positif sehingga memiliki relasi positif dengan orang lain dan pada akhirnya memberikan pengaruh positif pada kondisi psikologisnya. Kedua, implikasi praktis bagaimana mana perilaku amanah dapat diterapkan pada level individual dan organisasi. Secara individual, kepribadian amanah sangat bermanfaat bagi individu baik secara psikologis, sosial maupun agama. Masalahnya sekarang bagaimana mengajarkan nilai-nilai amanah pada individu terutama dalam lingkungan keluarga, sekolah maupun tempat kerja. Salah satunya caranya membuat suatu buku pedoman atau modul berdasarkan hasil penelitian dalam menentukan cara terbaik dalam mengajarkan, membentuk dan menginternalisasikan nilai-nilai amanah melalui pengasuhan, pengajaran dan pendidikan sehingga menghasilkan individu dengan kepribadian amanah. Sementara dalam tataran organisasi, bisnis dan ekonomi, konsep amanah menjadi penting untuk diterapkan (Mustofa, 2013; Saifullah, 2011). Amanah menjadi suatu nilai yang menjadi rujukan dan standar dalam operasional sebuah organisasi. Amanah menjadi salah satu nilai inti yang dipegang untuk kesuksesan sebuah perusahaan. Misalkan, hasil penelitian Kalbarini dan Suprayogi (2015) tentang aplikasi konsep amanah dalam bisnis, menunjukkan bahwa amanah merupakan bagian penting dalam proses bisnis karena dengan amanah perusahaan akan bertanggung jawab dan teliti dalam menjalankan peran dan tugasnya sehingga berdampak positif bagi perusahaan.

\section{Apa itu Amanah?}

Istilah amanah berasal dari konsep Islam yang berarti aman, tenteram, dan tenang (Abidin, 2017; Sari \& Sofia, 2018). Secara istilah, amanah memiliki pengertian yang luas, dalam dan kompleks (Pulungan, 2006; Rohman, 2011). Amanah tidak hanya berkaitan dengan masalah agama, melainkan masalah dunia (Agung \& Husni, 2016). Amanah bersifat multidimensi yang beragam, artinya amanah tidak hanya berorientasi pada hubungan interpersonal (horizontal), tetapi juga berkaitan dengan hubungan secara vertikal, dengan sang Pencipta. Selain itu, amanah juga berkaitan dengan bagaimana individu memperlakukan dirinya dan lingkungan (Abidin, 2017; Rohman, 2011; Sari \& Sofia, 2018; Tranajaya, 
2011).

Ada dua model dalam mengeksplorasi konsep amanah, pertama model top-down, yaitu penggambaran konsep berdasarkan dari teks dan para ahli agama. Pada model ini, peneliti mengeksplorasi konsep amanah berdasarkan teks, seperti Al-Quran, hadist dan pendapat ulama, kemudian dibuat penelitian atau alat ukur untuk diujikan secara empiris di lapangan. Beberapa penelitian yang menggunakan teks (Al-Quran, Hadist dan para ulama) dalam mengeksplorasi konsep amanah, seperti Abidin (2017), Pulungan (2006), Rohman (2011) menjelaskan amanah dalam perspektif Al-Qur'an. Sari dan Sofia (2018) menemukan beberapa tema amanah dalam Al Qur'an, yaitu keimanan, perilaku amanah, kapabilitas pengampu amanah, cara memperlakukan amanah, berkhianat, sifat amanah dan konsekuensi sifat amanah. Amanah juga dikaitkan dengan peran, dan tanggung jawab sebagai manusia Othman (2011), Rahman dan Shah (2015). Jadi dapat diartikan amanah sebagai kemampuan individu dalam melaksanakan tugas yang berasal dari Allah maupun manusia (Abidin, 2017; Mujib, 2017; Sari \& Sofia, 2018; Shuhari et al., 2019).

Selanjutnya, beberapa penelitian yang sampai pada tahap pengujian di lapangan seperti, Hasibuan et al. (2018) tentang amanah, dukungan sosial dan kesejahteraan subjektif, Tranajaya (2011) tentang amanah, motivasi dan etos kerja. Tekke et al. (2013) tentang model kepribadian amanah, sedangkan Ottman (2017), Sari dan Sofia (2018) melakukan konstruksi pengukuran amanah berdasarkan Al-Quran dan Hadist. Hasilnya, diperoleh instrumen amanah yang valid dan reliabel berdasarkan kaidah psikometri. Pada penelitian Ottman (2017) menunjukkan amanah berkaitan dengan fungsi manusia sebagai khalifah, yaitu amar ma'ruf (menyuruh kepada kebaikan) dan nahi munkar (melarang kepada keburukan) dan tanggung jawab kepada Allah, orang tua dan masyarakat. Sementara menurut "Kamus Besar Bahasa Indonesia Daring [Online Great Dictionary of Indonesian Language]" (2013), makna amanah mengalami penyempitan makna. Amanah cenderung dimaknai pada konteks hubungan interpersonal. Amanah diartikan sesuatu yang dititipkan kepada orang lain, setia, dan dapat dipercaya. Berdasarkan uraian pada model top down, dapat dilihat bahwa amanah memiliki definisi dan dimensi yang sangat luas dan beragam. Oleh karena itu, dapat diambil beberapa kesimpulan tentang amanah, yaitu 1) amanah merupakan karakter, sifat dan perilaku terpuji, 2) amanah adalah melaksanakan sesuatu berdasarkan perintah atau beban (tugas) yang diberikan kepada dirinya, 3) amanah memiliki konteks yang beragam, mulai hubungan dengan sang pencipta (Allah), manusia, diri sendiri dan lingkungan. Kedua, model bottom-up, yaitu penggambaran konsep berasal dari bawah (penelitian lapangan). Pada model ini, peneliti mengonsepsi amanah berdasarkan pengalaman sehari-hari individu melalui penelitian dan dibuat kesimpulan berdasarkan data yang diperoleh di lapangan. Beberapa penelitian yang sudah dilakukan oleh tim peneliti Center for Indigenous Psychology (CIP) Fakultas Psikologi UIN Suska Riau (lihat Tabel 1). CIP Fakultas Psikologi UIN Suska menggunakan model survei dengan pertanyaan terbuka dalam menggambarkan konsep amanah. Perspektif yang digunakan adalah psikologi indigenous, yaitu memahami fenomena psikologis berdasarkan konteks masyarakat (Kim \& Yang, 2006). 
Tabel 1

Rangkuman Hasil Penelitian Amanah CIP UIN Suska Riau

\begin{tabular}{|c|c|c|c|c|}
\hline No & Peneliti/tahun & Tema & Hasil & Ket \\
\hline 1 & $\begin{array}{l}\text { Agung dan Husni } \\
\text { (2016) }\end{array}$ & $\begin{array}{l}\text { Studi 1: konsep } \\
\text { amanah } \\
\text { Studi 2:alat ukur }\end{array}$ & $\begin{array}{l}\text { Amanah: karakter positif }(57,5 \%) \text { dan } \\
\text { melaksanakan tugas }(42,5 \%) \\
\text { Aspek amanah: integritas }(28,95 \%) \text {, } \\
\text { melaksanakan tugas (7 \%) dan } \\
\text { kebaikan hati }(5,8 \%) \\
\text { Pedagang amanah: kebaikan }\end{array}$ & 444 mahasiswa \\
\hline 2 & $\begin{array}{l}\text { Agung dan } \\
\text { Herwanto (2017) }\end{array}$ & Pedagang amanah & $\begin{array}{l}\text { Hati }(27,2 \%), \quad \text { jujur } \\
\text { profesional }(23,5 \%) \text {, } \\
\text { positif }(15,5 \%)\end{array}$ & 142 masyarakat \\
\hline 3 & Anatassia (2017) & Teman amanah & $\begin{array}{l}\text { Karakter }(41 \%) \text {, pelaksanaan tugas } \\
(39 \%) \text {, dan kualitas pertemanan }(20 \%) \\
\text { Peran }(43,5 \%) \text {, karakter }(42,2 \%) \text {, }\end{array}$ & 288 mahasiswa \\
\hline 4 & $\begin{array}{l}\text { Fitri dan Widyastuti } \\
\text { (2017) }\end{array}$ & Orangtua amanah & $\begin{array}{l}\text { integritas }(11,0 \%) \text {, } \\
\text { dan kebaikan hati }(3,3 \%)\end{array}$ & 444 siswa \\
\hline 5 & $\begin{array}{l}\text { Munthe dan } \\
\text { Widyastuti (2018) }\end{array}$ & Saudara amanah & $\begin{array}{l}\text { karakter }(59,5 \%) \text {, peran }(23,6 \%) \text {, dan } \\
\text { kebaikan hati }(16,9 \%)\end{array}$ & 288 mahasiswa \\
\hline 6 & Husni (2015) & Dosen amanah & $\begin{array}{l}\text { Pelaksanaan tugas }(57 \%) \text {, kualitas } \\
\text { personal }(17 \%) \text {, kompetensi }(15 \%) \text {, } \\
\text { pengasuhan }(9 \%)\end{array}$ & 265 mahasiswa \\
\hline 7 & Fitriyani (2014) & Pemimpin amanah & $\begin{array}{l}\text { Integritas }(60,8 \%) \text {, karakter }(36,4 \%) \text {, } \\
\text { dan kompetensi }(2,8 \%) \\
\text { Peran }(52 \%), \text { kebaikan hati }(25 \%) \text {, }\end{array}$ & 459 mahasiswa \\
\hline 8 & Widiningsih (2015) & Pasangan amanah & $\begin{array}{l}\text { jujur [200B?][200B?](10\%), dapat } \\
\text { berkomunikasi efektif }(7 \%) \text {, dan } \\
\text { religiusitas }(6 \%)\end{array}$ & 139 pasangan \\
\hline 9 & Vivik (2015) & Pribadi amanah & $\begin{array}{l}\text { Karakter positif }(74,2 \%,) \text {, ajaran Islam } \\
(12,4 \%) \text {, dampak amanah }(8,3 \%)\end{array}$ & 469 mahasiswa \\
\hline
\end{tabular}

Berdasarkan Tabel 1 dapat digambarkan konsep amanah dalam berbagai tempat dan variasi partisipan. Secara umum terdapat kesamaan dari berbagai penelitian khususnya bagaimana partisipan mengonsepsi amanah berdasarkan pengalaman. Beberapa tema amanah yang muncul relatif sama secara kata dan makna: karakter ( 7 kali), kebaikan hati $(5$ kali), pelaksanaan tugas (4 kali), peran (3 kali), integritas, jujur dan kompetensi (2 kali). Dilihat lebih detail, ada beberapa karakter yang sering muncul dalam menggambarkan individu amanah, yaitu terpercaya, tanggung jawab, melaksanakan tugas, jujur dan tepat janji. Tema-tema tersebut dapat dielaborasi lagi kepada tema yang lebih spesifik. Misalkan karakter dan integritas memiliki kesamaan. Menurut Mayer et al. (1995) integritas bagian dari karakter, Dia membagi karakter menjadi dua komponen, yaitu integritas (moral dan prinsip etik) dan kebaikan hati (benevolence). Integritas cenderung lebih rasional, sementara 
kebaikan hati cenderung emosional (Colquitt et al., 2007). Secara umum, tema tersebut dapat dibagi dua, yaitu pertama, karakter positif, meliputi kebaikan hati, integritas, dan jujur, Kedua, pelaksanaan tugas meliputi peran, kompetensi atau profesional.

Kedua model tersebut memiliki kelebihan dan kelemahan dalam menggambarkan konsep amanah. Model top-down, bersifat deduktif normatif, artinya penggambaran konsep berdasarkan norma yang ada di Al Qur'an dan Hadist (Mujib, 2006, 2017). Kelebihannya, dapat secara akurat, detail dan terperinci dalam menjelaskan konsep amanah. Amanah dilihat sebagai nilai yang ideal (seharusnya) sehingga secara teoretis sangat kuat dan komprehensif, namun memiliki kelemahan terutama dalam aplikasinya, bagaimana nilai amanah dapat diterapkan dan berguna dalam menjelaskan fenomena sosial. Sementara, model bottom up, lebih pada bersifat induktif-praktis yang memiliki kelebihan dalam menjelaskan konsep amanah, artinya konsep amanah lebih mudah dimengerti dan dipahami karena berdasarkan data empiris di lapangan. Kelemahannya, adalah penggambaran konsep amanah, cenderung tidak stabil, berubah, dan kadang berbeda dengan konsep teoretis, sehingga menimbulkan kesulitan pada peneliti dalam menjelaskannya. Bahkan terkadang, penggambaran konsep amanah tidak komprehensif, atau terjadi penyempitan makna karena pengalaman individu berbeda-beda dalam mengkonstruk konsep amanah.

Terlepas dari itu semua, psikologi sebagai suatu kajian empiris tentunya mendorong untuk pengujian yang berkelanjutan, sehingga menghasilkan suatu konsep teoretis yang lebih stabil dan kuat. Kedua model tersebut dapat saling melengkapi sehingga memperoleh konsep amanah yang kuat secara teoretis dan terbukti akurat di lapangan. Berdasarkan hasil review terhadap penelitian yang menggunakan kedua model tersebut, tidak terdapat perbedaan yang berarti dalam menjelaskan konsep amanah, artinya amanah dipahami sebagai bentuk tugas (tanggung jawab) yang harus dikerjakan dan amanah sebagai karakter terpuji, seperti terpercaya, tanggung jawab dan jujur. Perbedaannya, terletak pada konteks, yang cenderung pada hubungan interpersonal, misalkan penelitian Agung dan Husni (2016) menemukan bahwa orang yang amanah cenderung dipahami pada konteks hubungan dengan manusia, seperti perilaku jujur, menepati janji, menjaga rahasia, melaksanakan tugas, dan tanggung jawab. Hal ini membuktikan bahwa pemahaman masyarakat pada konsep amanah lebih menggambarkan relasi antar manusia.

\section{Amanah, Psikologi dan Islam}

Amanah erat kaitannya dengan sifat, karakter dan perilaku manusia. Oleh karena itu, amanah tidak dapat dipisahkan dari ilmu psikologi. Istilah amanah sudah banyak dibahas dalam perspektif Islam, sementara dalam ilmu psikologi, amanah sudah mulai banyak dibahas dan dieksplorasi. Secara arti, amanah memiliki beberapa padanan dalam konsep psikologi seperti kepercayaan, terpercaya, tanggung jawab dan jujur (Agung \& Husni, 2016; Othman, 2011; Tekke et al., 2013). Namun demikian, terdapat perbedaan terdapat khususnya dalam cakupan, makna dan arti. Misalkan, konsep amanah tidak hanya berkaitan hubungan interpersonal, melainkan juga mencakup hubungan dengan sang pencipta (vertikal). Implikasinya, konsep amanah berpotensi overlap dengan konsep psikologi, seperti kepercayaan, keterpercayaan, jujur, dan tanggung jawab. 
Selain itu, perlu diperjelas kedudukan konsep kepribadian amanah: apakah amanah merupakan sifat (trait), state (situasional) atau perilaku. Istilah trait dan state sering digunakan dalam menjelaskan kepribadian. Trait personality merujuk kecenderungan individu untuk beraksi pada situasi khusus yang cenderung stabil dan umum, sementara statesebaliknya cenderung bersifat temporal, tergantung dengan situasional atau lingkungan (Chaplin et al., 1998). Jika dilihat dari perspektif Islam berdasarkan sumber Al Qur'an dan Hadist, amanah cenderung merupakan sifat (Sari \& Sofia, 2018). Namun demikian, sifat amanah juga berubah sesuai dengan situasi (state) dan tercermin dalam bentuk perilaku-perilaku amanah. Intinya amanah merupakan sifat dasar seorang mukmin yang memengaruhi dia dalam berpikir, dan berperilaku. Misalkan, orang yang memiliki sifat (trait) amanah akan berbicara jujur, menepati janji dan melaksanakan apa yang diperintahkan. Namun apakah sifat amanah stabil pada semua kondisi? bisa iya atau tidak, artinya interaksi individu dengan lingkungan akan menentukan bagaimana individu berperilaku pada kondisi tertentu (state).

Lalu timbul pertanyaan: bagaimana kerangka kerja psikologis dalam memahami konsep amanah? berdasarkan konsep teoretis dan penelitian, konsep amanah dapat dilihat sebagai suatu sumber nilai, kebajikan, dan kepribadian positif-yang perlu dimiliki setiap individu. Semua konsep tersebut banyak dibahas dalam psikologi terutama psikologi kebajikan (psychology of virtue), yang berlandaskan pada psikologi positif, psikologi moral dan psikologi agama (Schnitker \& Emmons, 2017). Sandage dan Hill (2001) menyarankan enam dimensi untuk definisi kebajikan. yaitu (a) mengintegrasikan etika dan kesehatan; (b) diwujudkan sifat karakter; (c) sumber kekuatan dan ketahanan manusia; (d) tertanam dalam konteks budaya dan komunitas; (e) berkontribusi untuk tujuan hidup yang bermakna; dan (f) didasarkan pada kebijaksanaan. Berdasarkan kriteria tersebut, dapat disimpulkan amanah sebagai suatu virtue bagi individu maupun organisasi.

Pada awal perkembangan menunjukkan hubungan psikologi modern dan agama sebagai sesuatu yang tampak tidak dapat disatukan. Salah satunya disebabkan cara pandang, yang berbeda dalam memahami manusia. Psikologi modern cenderung memahami manusia berdasarkan apa yang dapat dilihat, diobservasi dan dikuantifikasi sehingga memahami manusia secara parsial, sedangkan agama (Islam) tidak hanya memandang manusia dari fisik, materialistis tetapi juga aspek pengalaman transendental, sehingga lebih holistik dalam memahami manusia (Haque, 2004; Mujib, 2017). Sekarang, studi tentang pengaruh agama terhadap individu telah banyak dilakukan dalam perspektif psikologi. Bahkan teori kepribadian modern menyatakan bahwa agama dan kepribadian memiliki hubungan yang terkait (Smither \& Khorsandi, 2009). Namun, tantangan belum banyak ahli psikologi Islam yang membahas amanah dalam perspektif psikologi, sehingga dalam menjelaskan kerangka psikologis konsep amanah berdasarkan data ilmiah menjadi kesulitan. Oleh karena itu, pemahaman dan pembahasan konsep amanah dapat dilihat berdasarkan teori kepribadian implisit (implicit theories of personality). Teori ini berlandaskan pada pengalaman-pengalaman individu dalam kehidupan sehari-hari. Menurut Borkenau (1992) teori kepribadian implisit merupakan sekumpulan gagasan tentang sifat manusia atau perilaku yang mereka perkirakan akan terjadi dalam diri seseorang. Fungsinya untuk menjelaskan dan memprediksi perilaku individu. Misalkan, individu yang suka berbicara akan memiliki kemampuan penyesuaian diri yang baik, atau individu yang rajin salat akan 
menjadi orang yang amanah.

Penelitian amanah dengan dengan menggunakan teori implisit telah dilakukan CIP UIN Suska Riau (lihat Tabel 1). Misalkan Fitri dan Widyastuti (2017) melakukan penelitian dengan bertanya kepada partisipan tentang gambaran orang tua amanah. Hasil penelitian menunjukkan bahwa orang tua amanah sebagai orang yang menjalankan peran, memiliki karakter, integritas dan kebaikan hati. Demikian juga, Agung dan Herwanto (2017) melakukan penelitian dengan bertanya kepada partisipan tentang ciri pedagang yang amanah. Pada studi tersebut pedagang amanah digambarkan sebagai tentang pedagang yang memiliki kebaikan hati jujur profesional dan karakter positif. Hasil-hasil penelitian tersebut menjelaskan konsep amanah dalam perspektif pengalaman individu-individu yang dapat digunakan untuk menjelaskan atau memprediksi perilaku amanah individu.

Dalam perspektif Islam, amanah dijelaskan salah satu ciri kepribadian para nabi dan orang mukmin (Abidin, 2017; Mujib, 2017; Tekke et al., 2013). Amanah dijelaskan dalam beberapa ayat di Al Qur'an. Umumnya penjelasan amanah terkait dengan peran dan tanggung jawab manusia di muka bumi. Misalkan, pada surat Al Mukminin ayat 8 berbicara tentang karakter seorang mukmin, yaitu menjaga amanah yang diberikan kepadanya. Bahkan, Islam memandang bahwa amanah merupakan salah satu sifat penting bagi seorang mukmin; sebagai penyempurnaan keimanan seseorang. Berdasarkan hadist yang berbunyi "Tidak sempurna iman seseorang yang tidak amanah, dan tidak sempurna agama orang yang tidak menunaikan janji". (HR. Ahmad). Menurut Islam, amanah tidak hanya dibahas dalam konteks relasi dengan Allah, tetapi juga dibahas dalam konteks hubungan dengan manusia dan lingkungan (Abidin, 2017; Mujib, 2017; Rohman, 2011).

Bagaimana amanah terbentuk dalam diri individu? Dalam psikologi, ada dua hal pandangan atau perdebatan bagaimana perilaku terbentuk, yaitu bawaan (nature) dengan lingkungan (nurture). Faktor bawaan cenderung bersifat menetap, stabil, sulit berubah, sedangkan faktor lingkungan (sosial) dinamis, mudah berubah dan situasional (Goddard, 2018). Beberapa ahli mengambil jalan tengah, yaitu proses terbentuknya perilaku karena interaksi personal dengan lingkungan. Demikian juga, amanah sebagai suatu kepribadian (trait) atau (state), tidak bisa dilepas dari faktor personal dan lingkungan. Keduanya berperan dalam membentuk kepribadian amanah. Individu akan menilai orang amanah berdasarkan keyakinan (belief), atau disebut amanah belief adalah keyakinan individu terhadap seseorang bahwa orang tersebut dapat amanah. Berdasarkan hasil penelitian, karakter yang muncul dalam menggambarkan amanah adalah terpercaya, tanggung jawab, melaksanakan tugas, jujur dan tepat janji (Agung \& Herwanto, 2017; Agung \& Husni, 2016; Fitriyani, 2014; Husni, 2015; Munthe \& Widyastuti, 2018).

Demikian sebaliknya, interaksi antara perilaku-lingkungan akan memperkuat atau memperlemah kepribadian (lihat Bagan 1). Faktor personal merupakan faktor yang bersumber dari internal individu yang meliputi atribut personal (umur, jenis kelamin, pendidikan), dan psikologis, seperti kepribadian, pengalaman, nilai, pengetahuan). Sementara faktor sosial/situasional, merupakan faktor yang berasal dari luar individu, seperti agama, budaya, pengasuhan, dan role model. Ketika individu memiliki kepribadian amanah, dia berniat untuk terus berperilaku amanah. Niat ini akan terwujud dalam bentuk perilaku dipengaruhi sejauh mana interaksi antara faktor personal dan 
lingkungan yang dialami individu. Ketika individu berperilaku sesuai dengan karakternya (pribadi amanah), maka individu dapat meningkatkan kesejahteraan psikologis, seperti penyesuain diri, self-esteem dan empati. Sebaliknya ketika individu berperilaku tidak amanah akan dapat menurunkan kesejahteraan psikologis individu, seperti depresi, dan kecemasan (Tekke et al., 2018).

Jadi dapat disimpulkan bahwa amanah sangat berhubungan dengan Islam dan psikologi. Hal tersebut karena amanah merupakan konsep asli dari Islam, kemudian diadaptasi dalam konteks masyarakat Indonesia. Amanah dapat dilihat dari dua sisi, yaitu sebagai tugas yang diberikan (dibebani) kepada individu dan sebagai karakter positif. Seringkali konsep amanah digunakan untuk menjelaskan perilaku-perilaku positif yang ada dalam masyarakat Indonesia, seperti terpercaya, tanggung jawab, jujur, dan menepati janji (lihat Bagan 1). Semua karakter tersebut sangat relevan dengan konsep psikologi, sehingga pendekatan psikologi dapat membantu dalam memahami perilaku sosial melalui pendekatan empiris, mulai dari apa dan bagaimana proses terbentuknya amanah, implikasi serta dinamika psikologi amanah.

\section{Gambar 1}

Model formasi kepribadian amanah

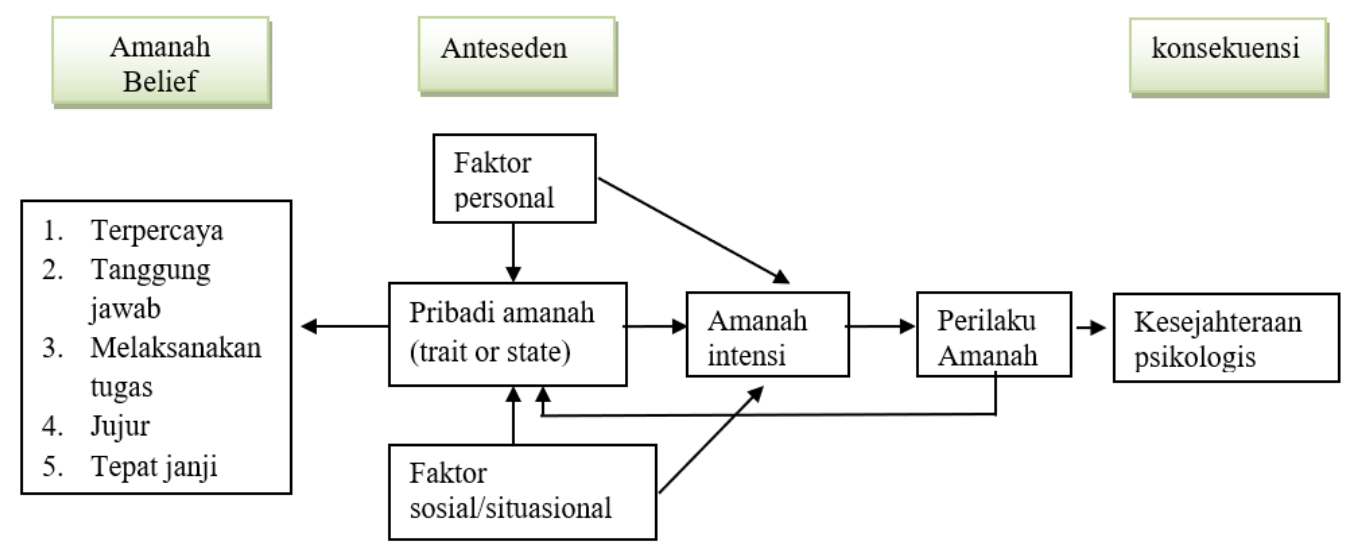

Pengukuran Amanah

Salah satu pertanyaan yang muncul adalah bagaimana mengukur amanah? Sebagai suatu kepribadian Islam (Islamic personality), amanah dapat diukur sebagaimana pengukuran kepribadian pada ilmu psikologi. Selama variabel (amanah) dapat dijelaskan secara operasional dan jelas indikatornya, maka variabel tersebut dapat diukur (Mujib, 2017). Beberapa penelitian sebelumnya menunjukkan pengukuran amanah telah dilakukan dengan berbagai cara, misalkan Othman (2011) mengukur ummatic personality Inventory (UPI), yang salah satu bagiannya tantang amanah. Hasilnya menunjukkan bahwa pengukuran amanah terdiri dari 28 aitem yang valid dan reliabilitas sebesar 0,92), dengan lima aspek, yaitu menyuruh kebaikan (amar ma'ruf) melarang keburukan (nahi munkar). Bertanggung jawab pada Allah, bertanggung jawab pada orang tua dan masyarakat. Selanjutnya, 
Tekke et al. (2013) memvalidasi skala amanah dari UPI pada 287 siswi. Hasilnya pengukuran amanah bersifat unidimensional, yang terdiri dari empat aspek, yaitu menyuruh kebaikan (amar ma'ruf), melarang keburukan (nahi munkar), bertanggung jawab pada Allah, dan bertanggung jawab kepada masyarakat. Secara umum pengukuran amanah dapat diterima secara psikometri dengan reliabilitas (alpha) sebesar 0,82.

Tranajaya (2011) melakukan pengukuran amanah dengan menggunakan skala Likert, dengan lima respons. Pengukuran amanah tersebut berdasarkan pada konsep yang dikembangkan oleh pakar psikologi Islam Ahmad Mubarok, yang terdiri dari dua aspek, yaitu amanah kepada Allah dan amanah kepada manusia, yang tercermin dalam pelaksanaan ibadah, dan muamalah, dengan beberapa indikator, yaitu patuh pada hukum, tanggung jawab, teguh memegang janji, komitmen dan jujur. Sari dan Sofia (2018) mencoba mengkonstruk pengukuran amanah berdasarkan perspektif Islam yaitu Al Qur'an, hadist, serta bahasa arab. Hasil penelitian menunjukkan bahwa skala amanah terdiri dua aspek yang bersifat kontinum, yaitu dapat dipercaya dan khianat. Individu dikatakan amanah jika memiliki skor tinggi pada aspek dapat dipercaya. Skala amanah tersebut memiliki reliabilitas yang baik secara psikometris, yaitu sebesar 0,96.

Sementara Agung dan Husni (2016) mencoba mengeksplorasi konsep amanah dengan cara berbeda, yaitu menggali konsep amanah dari bawah (Bottom-up), berdasarkan pengalaman sehari-hari dengan pendekatan kualitatif dengan satu pertanyaan terbuka. Hasil studi 1 dengan pendekatan kualitatif menunjukkan bahwa konsep amanah terdiri dari dua aspek, yaitu karakter positif dan pelaksanaan tugas. Pada studi 2 dilakukan konstruksi alat ukur amanah berdasarkan hasil studi 1. Hasil penelitian dengan analisis faktor eksploratori menunjukkan bahwa amanah terdiri dari tiga aspek, yaitu integritas, pelaksanaan tugas dan kebaikan hati, dengan reliabilitas Alpha sebesar 0,92.

Berdasarkan uraian yang telah dijelaskan dapat disimpulkan bahwa pengukuran amanah yang telah dilakukan menggunakan self report dalam bentuk kuesioner dengan menggunakan skala Likert atau self rating. Pengukuran kepribadian yang menggunakan self report memiliki keunggulan, seperti mudah, ekonomis dan cenderung menggambarkan kondisi aslinya karena diasumsikan dia lebih mengetahui dari yang lain ("ages of self-reports, informant reports and behavioural assessments", 2008), namun disisi lain self report memiliki keterbatasan, yaitu berpotensi menghasilkan bias respons, seperti social desirability, yaitu kecenderungan menjawab sesuai dengan keinginan atau harapan orang agar lebih kelihatan positif (Furr, 2011). Apalagi pengukuran yang berkaitan dengan virtue, partisipan tentu ingin dilihat sebagai orang yang amanah dibandingkan tidak amanah (faking good). Selain itu, ada self deception (penipuan diri sendiri), yaitu ketika individu sepenuhnya dan keliru meyakininya ia memiliki karakteristik yang diinginkan secara sosial dan bias konfirmasi diri, yaitu kecenderungan partisipan memilih situasi atau pengalaman yang sesuai (konfirmasi) dengan konstruk yang diukur (Fowers, 2014). Menurut Mujib (2017) ada beberapa hal yang diperhatikan dalam pengukuran variabel kepribadian Islam.

Pertama, apakah variabel kepribadian Islam perlu diukur? Atau hanya cukup dinilai?perdebatan menimbulkan pro kontra bahwa kepribadian merupakan suatu proses yang terus berkembang sehingga kurang tepat dilakukan pengukuran tetapi lebih pada evaluasi. Kedua, 
apakah variabel kepribadian Islam bersifat empirik atau meta empiris sehingga beberapa variabel sulit diukur secara empirik, seperti takwa. Ketiga, apakah hasil pengukuran kepribadian Islam berlaku sebagaimana hasil pengukuran kepribadian Islam lainnya, yang bersifat relatif, artinya ketika tidak ada pengaruh takwa dengan disiplin, maka rekomendasi penelitian agar tidak menjadi orang yang bertakwa. Kondisi ini menjadikan ajaran Islam tereduksi dan menjadi tidak terkonfirmasi dengan penelitian empiris. Keempat, apakah pengukuran kepribadian Islam atau kepribadian muslim. Kedua hal tersebut berimplikasi pada bagaimana menginterpretasi hasil pengukuran. Kepribadian Islam menggambarkan apa yang seharusnya terjadi, sementara kepribadian muslim menggambarkan apa yang ada pada orang muslim.

Kondisi tersebut harus menjadi perhatian bagi peneliti yang ingin melakukan penelitian tentang kepribadian Islam. Peneliti harus memahami filosofi dan metodologi dalam penelitian empiris, artinya ketika melakukan pengukuran kepribadian Islam yang bersifat normatif dan melakukan pengujian di lapangan, maka hasil penelitian tersebut bersifat deskriptif tentang apa yang diteliti pada subjek penelitian. Ketika tidak sesuai dengan seharusnya (idealnya) dalam agama Islam, maka harus dengan seksama dan hati-hati memahami hasil penelitian. Peneliti harus memperhatikan segala kemungkinan yang mempengaruhi pengukuran mulai dari alat ukur, karakteristik subjek dan bagaimana subjek mengisi instrumen. Dengan demikian hasil dan rekomendasi dalam penelitian lebih akurat dan tepat.

Pengukuran amanah, yaitu: pertama, operasional konsep amanah sangat menentukan bagaimana amanah diukur. Perbedaan definisi operasional menyebabkan pengukuran berbeda. Misalkan, (Ottman, 2017) menggunakan lima aspek dalam pengukuran amanah, sedangkan Agung dan Husni (2016), Sari dan Sofia (2018), Tranajaya (2011) menggunakan dua aspek. Namun demikian kalau dilihat lebih dalam dan detail, beberapa aspek memiliki kesamaan secara isi dan arti. Kedualebih fokus dan spesifik dalam pengukuran amanah. Hal tersebut penting untuk mengurangi overlap dengan variabel psikologis lainnya sehingga meningkatkan akurasi dalam pengukuran. Ketiga, menjelaskan kedudukan amanah dalam kepribadian: Apakah amanah sebagai sifat (trait) atau situasional (state)?. Trait dan state berimplikasi pada bentuk pertanyaan aitem. Keempat, menggunakan jenis pengukuran lain dan bentuk pertanyaan kreatif dan bersifat tidak langsung dalam mengukur konstruk. Hal tersebut lain untuk membantu meningkatkan validitas pengukuran (Fowers, 2014; Kruse et al., 2017).

\section{Peluang dan Tantangan}

Amanah merupakan salah satu nilai Islam yang telah diadopsi secara bahasa dan konteks ke dalam masyarakat Indonesia. Kajian tentang amanah telah banyak dilakukan dalam perspektif agama, ekonomi dan bisnis, dan psikologis. Namun demikian belum cukup kiranya untuk menjelaskan konstruk amanah secara jelas. Oleh karena itu, kesempatan ini merupakan peluang bagi ilmuwan dan peneliti di bidang psikologi khususnya yang tertarik dengan Psikologi Islam untuk mengeksplorasi, menguji dan mengaplikasikan konsep amanah dalam tataran teoretis maupun praktis. Secara teoretis dapat melalui penelitian dasar dan pengembangan teoretis berdasarkan pendekatan empirik. Misalkan, selama ini penelitian amanah cenderung memosisikan amanah sebagai variabel prediktor 
(Hasibuan et al., 2018; Tekke et al., 2018) sehingga masih terbuka peluang untuk mengeksplorasi amanah sebagai variabel kriteria. Sementara secara praktis, penerapan nilai-nilai amanah untuk pengembangan karakter positif menuju masyarakat kuat secara psikologis, melalui pelatihan, penyuluhan dan workshop.Ada beberapa tantangan pada penelitian amanah yang teridentifikasi, mulai dari tantangan teoretis, metodologis, pengukuran dan implikasi.

Pertama masalah teoretis Salah satu tantangan dalam penelitian virtue adalah keterbatasan pada teori (Fowers, 2014). Sebenarnya, amanah banyak dibahas dalam perspektif Islam, namun belum banyak teori yang berdasarkan studi empiris tentang amanah. Konstruk amanah berasal diri konsep Islam. Oleh karena itu, perlu pemahaman yang lebih komprehensif tentang amanah, khususnya dalam perspektif Islam sehingga mempunyai dasar yang kuat dalam melakukan penelitian empiris tentang amanah.

Kedua metodologi, selama ini penelitian amanah menggunakan penelitian dengan metode non eksperimen, seperti survei atau korelasional. Peluang untuk menggunakan penelitian eksperimen sangat terbuka khususnya untuk menguji konstruk amanah dalam konteks tertentu. Tantangannya, bagaimana melakukan pengukuran yang lebih akurat pada amanah, yang secara khusus didefinisikan sebagai sifat (trait) berperan penting dalam psikologis individu. Implikasinya, sifat trait cenderung kurang responsif terhadap manipulasi eksperimen karena cenderung lebih stabil dibandingkan state (Kruse et al., 2017). Selain itu, masalahnya, virtue bersifat individual (trait), sedangkan eksperimen lebih melihat perbandingan antar kelompok atau perlakuan (Fowers, 2014). Solusinya, amanah diposisikan sebagai state sehingga dapat dieksplorasi pada situasional tertentu dengan pendekatan eksperimen.

Ketiga pada umum pengukuran amanah menggunakan self report yang berpotensi menimbulkan bias respons. Tantangan berikutnya adalah bagaimana membuat alat ukur yang lebih akurat dan terpercaya sehingga mampu meningkatkan validitas dan konvergen dengan variabel psikologis lain. Salah satu caranya bisa menggunakan jenis pengukuran lain atau menggunakan cara untuk mendeteksi bias respons.

Keempat, implikasi. Ketika penelitian dalam rangka pengembangan teoretis telah dilakukan, maka langkah selanjutnya adalah bagaimana hasil penelitian diaplikasikan dalam pengembangan dan penguatan karakter positif, melalui pelatihan, sosialisi dan pembuatan modul praktis bagi masyarakat untuk dapat digunakan dalam kehidupan sehari-hari.

\section{Penutup}

Amanah merupakan salah satu kepribadian yang penting bagi individu, dan masyarakat. Kepribadian amanah bermanfaat pada diri individu, masyarakat, organisasi bahkan Negara. Misalkan, banyak kejadian-kejadian negatif di masyarakat seperti kriminalitas, korupsi dan konflik, yang salah satunya disebabkan hilangnya perilaku amanah di masyarakat. Apa itu amanah? Pembahasan konsep amanah telah banyak dalam perspektif Islam. Dalam Islam, konsep amanah memiliki definisi luas dan mendalam. Amanah dikaitkan dengan peran dan tanggung jawab manusia 
sebagai makhluk ciptaan di muka bumi. Amanah tidak hanya berkaitan dengan hubungan antar manusia dan lingkungan (horizontal) tetapi juga hubungan dengan Allah (vertikal). Implikasinya, amanah menjadi konstruk yang bersifat multidimensi dan kompleks.

Dalam perspektif psikologi, amanah mulai banyak dieksplorasi melalui penelitian survei korelasional maupun kualitatif. Beberapa konsep yang relevan atau mirip dengan amanah, yaitu terpercaya, kepercayaan, jujur dan tanggung jawab. Berdasarkan review penelitian tentang amanah dapat disimpulkan bahwa amanah dilihat dari dua hal, pertama amanah sebagai general virtue (kebajikan umum), artinya amanah merupakan konsep kebajikan yang bersifat umum yang di dalamnya terdapat spesifik kebajikan (specific virtue), seperti terpercaya, tanggung jawab, dan jujur. Amanah juga dapat dilihat sebagai kemampuan individu menjalankan peran dan tugasnya.

Di Indonesia, penelitian tentang konsep amanah masih belum banyak dilakukan. Studi-studi tentang amanah dalam perspektif psikologi perlu dikembangkan secara komprehensif dan berkelanjutan. Kompleksnya konsep amanah merupakan sebuah peluang dan tantangan untuk meneliti lebih lanjut konstruk amanah dalam perspektif psikologi dengan memperhatikan konteks keindonesiaan. Beberapa hal yang menjadi perhatian dalam penelitian amanah adalah, teoretis, metodologis, pengukuran, dan aplikasi nilai amanah dalam tataran praktis bagi individu, dan organisasi.

\section{Pernyataan}

\section{Ucapan Terima Kasih}

Artikel ini terinspirasi dari penelitian-penelitian tentang amanah yang dilakukan oleh peneliti CIP Psikologi UIN Suska Riau. Oleh karena itu, saya mengucapkan terima kasih kepada Pimpinan Fakultas Psikologi UIN Suska Riau, Dosen, Tim Peneliti CIP dan para asisten atas referensi dan kesempatan, yang diberikan dalam penulisan artikel ini.

\section{Pendanaan}

Penulis tidak menerima bantuan pendanaan dalam penulisan artikel ini

\section{Kontribusi Penulis}

Tulisan ini merupakan telaah literatur dari berbagai kajian pustaka dan penelitian tentang konsep Amanah khususnya di CIP Fakultas Psikologi UIN Suska Riau dan Penulis adalah tunggal yang menyelesaikan dari bagian pengantar, hasil, dan penutup

Pernyataan Konflik Kepentingan

Tidak ada potensi konflik kepentingan yang dilaporkan oleh penulis

\section{Orcid ID}

Ivan Muhammad Agung https:/ / orcid.org/0000-0003-1665-1863 


\section{Daftar Pustaka}

Abidin, F., Z \& Khairudin. (2017). Penafsiran ayat-ayat amanah dalam al-qur'an [the interpretation of amanah verses in al-qur'an]. Jurnal Syahadah, 5(2), 120-144.

Ages of self-reports, informant reports and behavioural assessments. (2008). Enquire, 1(1), Measuring personality constructs: The advantages and disadvant1-19.

Agung, I. M., \& Herwanto, J. (2017). Pedagang yang amanah: Studi eksplorasi dengan pendekatan psikologi indigenous [trustworthy merchant: An exploratory study with psychological approach]. Psympathic : Jurnal Ilmiah Psikologi, 4(1), 133-140. https: / / doi.org/10.15575/ psy. v4i1.1259

Agung, I. M., \& Husni, D. (2016). Pengukuran konsep amanah dalam pendekatan kualitatif dan kuantitatif [measurement of amanah concept with qualitative and quantitative approach]. Jurnal Psikologi, 43(3), 194. https://doi.org/10.22146/jpsi.11233

Anatassia, D. F. (2017). Apakah kamu teman yang amanah ? psikologi indijinus : Teman yang amanah pada masyarakat melayu [are you an amanah friend ? indigenous psychology : An amanah friend in melayu community]. Jurnal Psikologi, 13(1), 41-47. http:/ / ejournal.uin-suska.ac.id / index.php/psikologi/article/view/2769

Borkenau, P. (1992). Implicit personality theory and the five-factor model. Journal of Personality, 60(2), 295-327. https://doi.org/10.1111/j.1467-6494.1992.tb00975.x

Chaplin, W. F., John, O. P., \& Goldberg, L. R. (1998). Conceptions of states and traits: Dimensional attributes with ideals as prototypes. Journal of Personality and Social Psychology, 54(4), 541-557. https://doi.org/10.1037/0022-3514.54.4.541

Colquitt, J. A., Scott, B. A., \& LePine, J. A. (2007). Trust, trustworthiness, and trust propensity. Journal of Applied Psychology, 92(4), 909-927. https:/ / doi.org/10.1037/0021-9010.92.4.909

Fitri, A. R., \& Widyastuti, A. (2017). Orang tua yang amanah: Tinjauan psikologi indijinus [amanah parents: Indigenous psychology analysis]. Jurnal Psikologi Sosial, 15(1), 12-24. https:/ /doi.org/ $10.7454 / j p s .2017 .2$

Fitriyani, E. (2014). UIN Suska Riau.

Fowers, B. J. (2014). Toward programmatic research on virtue assessment: Challenges and prospects. Theory and Research in Education, 12(3), 309-328. https:/ / doi.org/10.1177/1477878514546064

Furr, R. . (2011). Scale construction and psychometrics for social and personality. New Delhi, SAGE Publications Ltd. https://doi.org/https://doi.org/10.4135/9781446287866

Goddard, M. J. (2018). Extending b. f. skinner's selection by consequences to personality change, implicit theories of intelligence, skill learning, and language, 22(4), 421-426. https:/ /doi.org/ 10.1037/gpr0000168

Hamka. (1990). Tasauf modern. Jakarta, Pustaka Panji Mas.

Haque, A. (2004). Psychology from islamic perspective: Contributions of early muslim scholars and challenges to contemporary muslim psychologists. Journal of Religion and Health, 43(4), 357-377. https://doi.org/10.1007/s10943-004-4302-z 
Hasibuan, M. A. I., Anindhita, N., Maulida, N. H., \& Nashori, H. F. (2018). Hubungan antara amanah dan dukungan sosial dengan kesejahteraan subjektif mahasiswa perantau[the correlation between amanah and social support with subjective well-being of out-of-state student]. Psikohumaniora: Jurnal Penelitian Psikologi, 3(1), 101. https:/ / doi.org/10.21580/pjpp.v3i1.2214

Husni, D. K. (2015). Amanah pada dosen [amanah among lecturers] (tech. rep.). Universitas Islam Sultan Syarif Kasim Riau.

Kalbarini, R. Y., \& Suprayogi, N. (2015). Implementasi akuntabilitas dalam konsep metafora amanah di lembaga bisnis syariah (studi kasus : Swalayan pamella yogyakarta)[implementation of accountability of metaphoric concept of amanah in sharia business institution (case study: Pamella supermarket yogyakarta)]. Jurnal Ekonomi Syariah Teori dan Terapan, 1(7), 506. https: //doi.org/10.20473/vol1iss20147pp506-517

Kamus besar bahasa indonesia daring [online great dictionary of indonesian language]. (2013). http: //bahasa.kemdiknas.go.id/kbbi/index.php

Kholmi, M. (2012). Akuntabilitas dan pembentukan perilaku amanah dalam masyarakat islam [accountability and formation of amanah behavior in islamic society]. Jurnal Studi Masyarakat Islam, 15(1), 63-72. https:/ / ejournal.umm.ac.id/index.php/salam/article/view /1099

Kim, U., \& Yang, K., K.S \& Hwang. (2006). Indigenous and cultural psychology: Understanding people. New York, Springer.

Kruse, E., Chancellor, J., \& Lyubomirsky, S. (2017). State humility: Measurement, conceptual validation, and intrapersonal processes. Self and identity, 16(4), 399-438. https: / / doi . org / 10.1080 / 15298868.2016.1267662

Mayer, R. C., Davis, J. H., \& Schoorman, F. D. (1995). An integrative model of trust. Management, 20(3), 709-734. https://doi.org/10.5465/AMR.1995.9508080335

Mujib, A. (2006).

Mujib, A. (2017). Teori kepribadian perspektif psikologi islam [theories of personality islamic psychology perspective] (2nd ed.). Jakarta, PT Raja Grafindo.

Munthe, R. A., \& Widyastuti, A. (2018). Saudara yang amanah: Tinjauan psikologi indijinus [amanah relatives: An indigenous psychology study]. Jurnal Psikologi Sosial, 15(1), 25-34. https: / / doi. org/10.7454/jps.2017.3

Mustofa. (2013). Enterpreneursip syariah: (menggali nilai-nilai dasar manajemen bisnis rasulullah) [sharia entrepreneurship: (delving into the basic business management values of the prophet]. Al-Mizan, 9(1), 29-46.

Othman, N. (2011). Exploring the ummatic personality dimensions from the psycho-spiritual paradigm. International Journal of Psychological Studies, 3(2), 37-47. https: / / doi.org/10.5539/ ijps.v3n2p37

Ottman, J. (2017). The new rules of green marketing: Strategies, tools, and inspiration for sustainable branding. https://doi.org/10.4324/9781351278683

Pulungan, S. (2006). Wawasan tentang amanah dalam al-quran [knowledge about amanah in al-quran] (Doctoral dissertation). UIN Syarif Hidayatullah. 
Rahman, Z. A., \& Shah, I. M. (2015). Measuring islamic spiritual intelligence. Procedia Economics and Finance, 31(15), 134-139. http:/ / dx.doi.org/10.1016/S2212-5671(15)01140-5

Rohman, F. (2011). Konsep dan metode penanaman nilai amanah dalam al-qur'an (studi tematik ayat-ayat amanah) [concept and methods of the cultivation of amanah values in al-qur'an (a thematic study of amanah verses] (Doctoral dissertation). Universitas Islam Negeri Sunan Kalijaga. http:/ / digilib. uin-suka.ac.id/6950/1/BAB\%20I,\%20V,\%20DAFTAR\%20PUSTAKA.pdf

Saifullah, M. (2011). Etika bisnis islami dalam praktek bisnis rasulullah [islamic business ethics in the business practice of the prophet]. Walisongo: Jurnal Penelitian Sosial Keagamaan, 19(1), 127. https: //doi.org/10.21580/ws.19.1.215

Samsudin, S. B., \& Islam, S. (2015). Value of al- amanah in human ' life. International Journal of Scientific and Research Publication, 5(4), 1-3. http:/ / www.ijsrp.org/research-paper-0415/ijsrp-p40112. pdf

Sandage, S. J., \& Hill, P. C. (2001). The virtues of positive psychology: The rapprochement and challenges of an affirmative postmodern perspective. Journal for the Theory of Social Behaviour, 31(3). https://doi.org/10.1111/1468-5914.00157

Sari, E. P., \& Sofia, N. (2018). Konstruksi alat ukur amanah dalam perspektif al quran - hadis [construction of amanah measuring instrument in the perspective of al-quran - hadits]. Jurnal Psikologi Islam, 5(1), 13-26. https://www.jpi.api-himpsi.org/index.php/jpi/article/view/55

Schnitker, S. A., \& Emmons, R. A. (2017). The psychology of virtue: Integrating positive psychology and the psychology of religion. Psychology of Religion and Spirituality, 9(3), 239-241. https: / / doi.org/10.1037/rel0000133

Shuhari, M. H., Hamat, M. F., Nasri, M., Basri, H., Mohd, W., Firdaus, K., Khairuldin, W., Sultan, U., Abidin, Z., Wahab, M. R., Ahmad, E., Engku, Z., \& Mamat, A. (2019). Concept of al-amanah (trustworthiness) and al- mas ' uliyyah (responsibility) for human's character from ethical islamic perspective. Journal of Legal, Ethical and Regulatory Issues, 22(1), 1-5.

Smither, R., \& Khorsandi, A. (2009). The implicit personality theory of islam. Psychology of Religion and Spirituality, 1(2), 81-96. https://doi.org/10.1037/a0015737

Suprihatiningrum, J., \& Premono, S. (2012). Student perception against the concept of fathonah, amanah, shidiq, and tabligh (fast) and its relation to the readiness to be a professional and characterized teacher. Annual International Conference on Islamic Studies (AICIS XII), 2246-2251. https://core.ac.uk/download/pdf/34212398.pdf

Tekke, M., İsmail, N., Mohamed Adnan, M. A., \& Othman, N. (2013). Students' islamic personality on amanah: A structural modelling approach. Journal of Social Sciences and Humanities.

Tekke, M., Watson, P. J., Kayadibi, S., \& Chen, Z. J. (2018). Amanah and muslim identity: Relationships with religious and psychological adjustment in malaysia. Journal of Religion and Health. https: //doi.org/10.1007/s10943-018-0690-3

Tranajaya, A. (2011). Hubungan amanah dan motivasi kerja dengan etos kerja kader hidayatulloh [the correlation between amanah and work motivation with the work ethic of hidayatulloh cadres] (Doctoral dissertation). Universitas Indonesia. 
Agung || Psikologi Amanah

Vivik, Y., S \& Khadafi. (2015). Memaknai pribadi yang mampu menjaga amanah : Pendekatan psikologi indigenous [interpreting a personality that can maintain amanah: An indigenous psychology approach] (tech. rep.). Universitas Islam Negeri Sultan Syarif Kasim Riau.

Widiningsih, A., Y \& Marethi. (2015). Amanah pada pasangan menikah dalam budaya melayu [amanah among married couples in malay culture] (tech. rep.). Universitas Islam Negeri Sultan Syarif Kasim Riau. 